University of Louisville

ThinkIR: The University of Louisville's Institutional Repository

Electronic Theses and Dissertations

8-2006

\title{
Evolution or revolution in the labor movement : business unionism versus social unionism.
}

Jo Ann Shumate 1958-

University of Louisville

Follow this and additional works at: https://ir.library.louisville.edu/etd

\section{Recommended Citation}

Shumate, Jo Ann 1958-, "Evolution or revolution in the labor movement : business unionism versus social unionism." (2006). Electronic Theses and Dissertations. Paper 1324.

https://doi.org/10.18297/etd/1324

This Master's Thesis is brought to you for free and open access by ThinkIR: The University of Louisville's Institutional Repository. It has been accepted for inclusion in Electronic Theses and Dissertations by an authorized administrator of ThinkIR: The University of Louisville's Institutional Repository. This title appears here courtesy of the author, who has retained all other copyrights. For more information, please contact thinkir@louisville.edu. 


\title{
EVOLUTION OR REVOLUTION IN THE LABOR MOVEMENT: BUSINESS UNIONISM VERSUS SOCIAL UNIONISM
}

\author{
By \\ Jo Ann Shumate \\ B.S., University of Louisville, 2001
}

\author{
A Thesis \\ Submitted to the Faculty of the \\ Graduate School of the University of Louisville \\ In Partial Fulfillment of the Requirements \\ For the Degree of
}

Master of Arts

Department of Sociology

University of Louisville

Louisville, Kentucky

August 2006 
EVOLUTION OR REVOLUTION IN THE LABOR MOVEMENT: BUSINESS UNIONISM VERSUS SOCIAL UNIONISM

By

Jo Ann Shumate

B.S., University of Louisville, 2001

A Thesis Approved on

May 24, 2006

By the Following Thesis Committee:

Thesis Committee Chair 


\section{DEDICATION}

This thesis is dedicated to my mother,

Mrs. Mary L. "Mayme" Shumate

From whom I inherited the strength

To carry on. 


\section{ACKNOWLEDGEMENTS}

I would like to thank my Committee Chair, Dr. Cynthia Negrey, for her patience and her professional guidance. I would also like to thank my other committee members, Dr. Avery Kolers, for sharing his knowledge of the modern labor movement with enlightening comments, and Dr. Clarence Talley, for his mentoring and encouragement throughout my graduate school experience. I also wish to thank my dear friend, Danielle Albright, who convinced me to go after my Master's degree, and who helped me along when statistics class got tough. Mostly, I wish to thank my daughter, Allison Ryan, who has put up with her grumpy mom all through my back-to-school years. To all my friends and family, especially Nina Louise, thanks for the support and encouragement, the help with child care and the housekeeping chores, but most of all, thanks for the love-- I could not have done it without you! 


\section{ABSTRACT \\ EVOLUTION OR REVOLUTION IN THE LABOR MOVEMENT: \\ BUSINESS UNIONISM VERSUS SOCIAL UNIONISM \\ Jo Ann Shumate}

August 2006

This is a study of the American labor movement, particularly how national labor policy is enacted at the local level. Specific differences between business unionism and social movement unionism, as defined in the literature, are combined and analyzed. Local unions are compared and contrasted in order to explore which will be more effective in the growth of the labor movement of the $21^{\text {st }}$ century.

This is a case study of three different types of local unions: craft, service sector, and public sector. In-depth interviews were conducted with two to three officials from each union. The questions covered five topics which were used to determine their business or social union status. The questions sought out the locals' role in the following areas: social welfare, politics, organizing, community coalitions, advancement of women and minorities, and affiliation with either the AFL-CIO or the Change to Win Federation.

It was concluded that the craft union exemplified all of the characteristics of business unionism; the service sector union was a model of social unionism; and the public sector union displayed characteristics of both, but 
leaned mostly towards social unionism. The service sector union, therefore, is more predisposed than the others to create substantial growth in the new labor movement. 


\section{TABLE OF CONTENTS}

\section{PAGE}

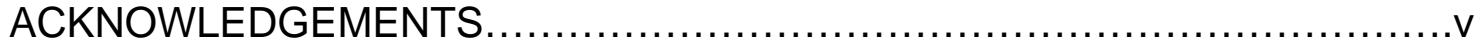

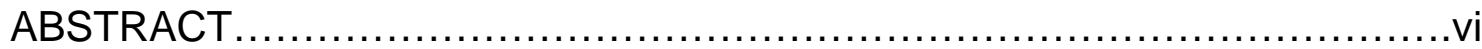

\section{CHAPTER}

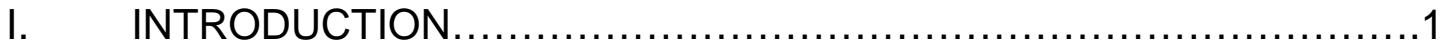

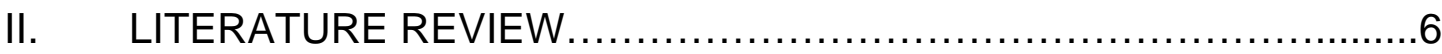

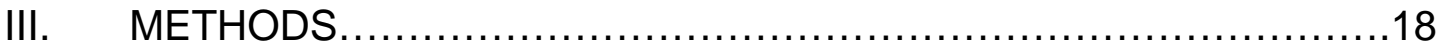

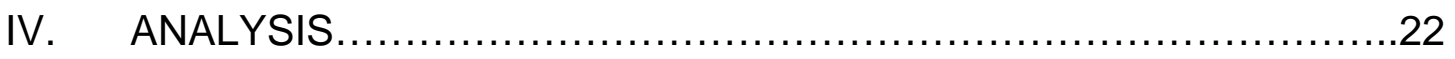

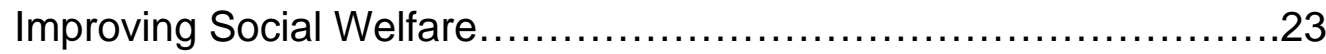

Political Issues and Candidates......................................28

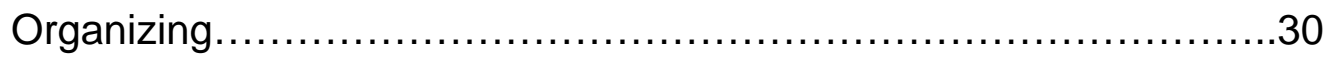

Race and Gender......................................................

AFL-CIO Policy, the Change to Win Federation........................38

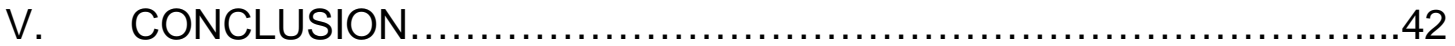

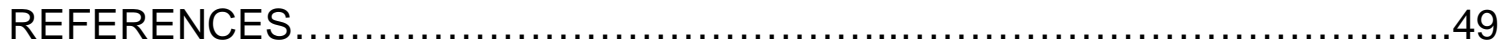




\section{INTRODUCTION}

The workplace in America is a complex and competitive place in the new millennium. Its intricacies have been shaped and changed immensely in the last 200 years, and the legacy of the Industrial Revolution is one fraught with domination, exploitation, and discrimination. The workers in the marketplace of labor have generally been pitted against one another, especially as new groups enter into competition with existing ones. The labor movement in America has not always been adept at dealing with various groups, although corporate America has been able to increase their profits through their exploitation. In the past, unions have sometimes acted as gatekeepers to exclude groups such as women and racial and ethnic minorities, but in the last 30 years even mainstream unions have been forced to reform these discriminatory practices.

The decline in union membership in the last quarter of the twentieth century has forced the labor movement to rethink its policies. The compound phenomena of deindustrialization and globalization are two of the major factors which caused this decline. The economy in the United States, as well as in the rest of the developed world, has undergone a sea change in the last 50 years. Like the change from an agricultural to an industrial society, we are in the midst of an overarching shift from a manufacturing economy to one based on service 
and technology. This has resulted in a serious dearth of the good-paying unskilled or semi-skilled jobs that were available from the end of WWII through the 1970s. Technology itself has eliminated many of these jobs, and what is left of the manufacturing industry has been scattered far and wide. Producers are more specialized than ever, and factories are smaller and therefore more mobile. They have left the northern urban industrial centers and gone south to more rural locations, seeking to escape the higher cost of union labor. If this strategy fails, many leave the country altogether, going to undeveloped or developing nations where labor is extremely cheap, in order to increase profits in an ever more intense world marketplace (Freeman and Medoff 1984, Nissen 2002).

For organized labor, the implications of this shift are many. The traditional industrial and craft labor movement has seemed to respond to these changes much more slowly than has corporate management. The monumental growth of the service sector in America dictates a shift in the labor movement towards organizing this sector. Many service industries have not traditionally been exposed to the labor movement but have in recent years seen some progress towards collective bargaining agreements. Some professional organizations, such as the National Education Association, have morphed into what could be called unions. And some traditional unions have begun to recognize that, in order to survive, they must begin to court the segment of the working population that 
includes a broad range of professionals, office and retail clerks, hotel and restaurant staff, and all manner of service workers.

Another factor in the decline of union membership is the practice known as union-busting. This was performed particularly well by Ronald Reagan in the 1980s when he fired all the air traffic controllers who belonged to the Professional Air Traffic Controllers Organization (PATCO), because they struck for better wages and conditions. Thus began a new trend in the modern backlash against the labor movement. Companies use these tactics to get rid of existing unions or to keep out union organizers. They sometimes go to great lengths, such as hiring legal advisers and consultants to do battle with labor. The tactic most easily accomplished, however, is the use of company rhetoric, which derides unions from the workers' point of view. The workers are led to believe that unions are merely dues-collecting entities that do nothing for the workers but could somehow destroy the company. Management relies on the gullibility of and plays on their workers' loyalty when they spread this propaganda. This tactic has been especially successful in the retail area of the service sector (Ehrenreich 2001).

What has been called the secondary labor market is the location of "bad" part time jobs, with which workers struggle to obtain basic necessities (Tilly 1996). Many service sector workers are relegated to part time or temporary work due to the nature of the new economy. These positions are generally low paying 
and have few benefits, which were first won by labor unions in post WWII America. Also called contingent work, in today's economy these jobs are sometimes the only available option to unskilled or semiskilled workers.

Women and minorities disproportionately fill more of these lower paying jobs in service industries (Spalter-Roth and Hartmann 1998). White males, who were and are better represented in the industrial trades, are sometimes underrepresented in the less-skilled jobs of the service sector. This type of job segregation is the result of America's long history of discrimination and inequality in the workplace. White women have entered the labor market in increasing numbers since the 1950s, and women of color have been moving away from domestic work since the Civil Rights legislation of the 1960s. The increase in women in the labor market has not necessarily increased their standard of living, however. Because women are relegated to lower-paying jobs, or possibly because these jobs are filled by women, the phenomenon known as the feminization of poverty is perpetuated (Reskin and Padavic 1994). This problem is a result of the pay gap between men and women and the increase in the rate of single mothers. It has lessened in recent years, but it is still an issue which can and should be addressed by the labor movement. In light of the welfare reforms of 1996, former recipients have been turned out into the labor force and exploited by low-wage employers. Many of these workers can be helped by the benefits of union membership. 
The new policies of the American Federation of Labor -- Congress of Industrial Organizations (AFL-CIO) feature inclusion of women and minorities in the rank and file and in leadership positions. The reasoning behind this is debatable; did the labor unions initiate inclusionary policies to help those traditionally excluded, or was it out of desperation to increase rank and file membership? If the latter is true, then the unions are being true to their bureaucratized, institutional selves: nothing has really changed in the last 50 years. If the former is true, this means that labor leaders are committed to bringing social movement status back to American labor unions.

The new policies also demand that AFL-CIO affiliates put much of their energies and budgets into organizing the unorganized. This is problematic because from WWII until the mid to late 1990s, most union affiliates spent less than $3 \%$ of their operating budgets on organizing new workers and mostly busied themselves maintaining benefits for their existing members (Tait 2000). The lack of organizing efforts is linked to the bureaucratization of unions, first begun in the 1950s, when labor struck an unwritten "social contract" with business (Sweeney 1996). This accord led to many gains for labor, such as higher wages, health insurance, and pension benefits, but the agreement included their promise to protect the capitalist system and the status quo. The contract was broken by business repeatedly in the 1970 s and 80 s, when many unions were forced to take pay and benefit cuts as well as declining membership. 
Although the 1990s brought an economic boom to America, unions were slow to take advantage of it. Most of the economic growth was in the service sector, a largely unorganized segment of workers, and labor leaders were generally from traditional industrial areas that are much more conducive to collective bargaining. The relative complacency of leadership led to the unprecedented election of John Sweeney as AFL-ClO president in 1995. Along with his running mates, Rich Trumka and Linda Chavez-Thompson, Sweeney promoted a "new voice" platform, which targeted service sector workers (Sweeney 1996). His background in the Service Employees International Union (SEIU) much better prepared Sweeney for service sector organizing than his predecessor, Lane Kirkland. And in the year 2000, labor leaders brought forth another new program, dubbed "Changing to organize, organizing for change" (Fletcher and Hurd 2000).

These policy changes are attempts to be more inclusive at the leadership level as well as the rank and file. The purpose of this study is to take a closer look at the implementation of these policies. A look at national trends in labor union membership will show whether or not women and minorities are gaining a stronger foothold in the movement. But a closer examination at the local level is even more illuminating. I interviewed labor organizers and officials whose unions are affiliated with the AFL-CIO. The analysis compared a traditional craft union, an industrial union, and a public sector union. Because these three types of 
unions serve different sectors of the labor market, they may vary widely in their approaches to organizing and inclusion of women and minorities. In some cases, particularly craft unions, membership has traditionally consisted only of white males. Due to the Civil Rights Act of 1964 and its eventual enforcement in the 1970s, these unions were forced to bring in some women and minorities. This study attempted to discover if these unions' goals signify inclusion or merely a continuation of tokenism.

Some unions have significantly stepped up their organizing campaigns, especially those industrial unions whose membership is in the service sector. I inquired about how faithfully these locals are adhering to the organizing policies, especially in regard to the recruitment of women and minorities. At least some of the difficulties of implementing the new AFL-CIO policies surfaced, and the comparison of these unions revealed the complexity of the modern labor movement. But the main criteria determined whether these locals are simply attempting to increase their membership, or whether in fact they are "changing to organize, organizing for change". 


\section{LITERATURE REVIEW}

Labor unions have a long and varied history in the United States; they have developed differently here as compared to European countries. Socialist

forces were in the forefront of American labor from the $19^{\text {th }}$ century until the mid $20^{\text {th }}$ century. The McCarthy era saw the purge of the last of the communists/socialists, who were mainly in the Congress of Industrial Organizations (ClO), in the 1950s. By the time of the AFL-CIO merger (1955), the social contract between big business and labor had been struck and "business unionism" was the norm in America's capitalist economy.

Labor in the $20^{\text {th }}$ century was highly influential in American politics and has been responsible for passage of a large amount of legislation. Although it has never been a direct force as it has in Europe, which has resulted in the more recent trend of being left behind in national politics, labor law does have a rich history in the U. S. Many of these laws have benefited workers, from the Fair Labor Standards Act (FLSA) of 1938, to the Family and Medical Leave Act of 1993 (FMLA), but none of this legislation has kept pace with economic trends such as deindustrialization and globalization. This has factored into the decline in union membership; labor has not always been able to gain enforcement of the laws that it helped to create (Galenson 1986). 
The labor movement, in its infancy, was concerned not only with wages and benefits but also with the social "uplifting" of its members (Freeman and Medoff 1984). This included cultural improvements for the working class as well as economic gain. It was usually in business' best interest, however, to keep the aspirations of its workforce to a minimum, and to be a hegemonic force in the process of production. These oppositional forces were brought together with the social contract of the postwar era.

Those who claim that unions will meet their demise in the near future claim that an oppositional work environment is counterproductive in today's competitive economy (Green 1996). They claim that "company unions", such as those espoused by the Japanese style of management, work best in a culture that values consensus. There is some debate, however, whether these environments have truly produced a voice in the workplace for those who need it (Besser 1996). In any case, these styles have mainly been tested only in the manufacturing sector of the economy, leaving the unskilled workers of the service sector in the lurch. These are the people who need more democracy in the workplace, more of a voice to express their concerns and demands.

The decline in union membership has been the subject of much recent scholarship, and rightly so. In the 1950s, union membership reached its peak at $35 \%$ of all workers. By the 1990 s that figure had dwindled to $13.5 \%$ overall, and a mere 9\% in the private sector (Sweeney 1996; Nissen 1999; Eimer 2002). There 
are five major factors at work in this decline; opinions vary on the weight of each factor, but all are pointed to as contributing to loss in union membership. The first, historically and to some the primary cause, is deindustrialization (Weinbaum 1999). The second, which to some extent is involved with the first, is globalization. The remaining factors concern labor's response to the first two and are the main sources of concern for many scholars who claim that unions are mostly to blame for their own decline (Nissen 1999). In their opinion, the primary factors in decline are labor's loss of political and legal strength, its general failure to organize new members in the recent past, and the anti-union hostility of corporate America. It is true that labor's power and influence have suffered because of its fewer numbers of rank and file members. How does one weigh these complex and sometimes inevitable factors? Some labor scholars claim that economic change is responsible for less than one-third of union decline, that the latter three factors are to blame for the bulk of waning membership (Chaison and Rose 1991, in Bronfenbrenner 1998).

Regardless of the forces involved, labor has begun its answer to the decline. Labor movement leaders and scholars alike agree that, in order to survive, unions in America must make some vast changes. But the direction and scope of these changes, as well as their ability to be implemented, are subject to debate. Since business unionism has been abandoned by all but the most entrenched industries, a different modus operandi must be sought out and 
utilized by labor. The new guard believes that the next step for labor is what Sweeney and labor scholars call "social unionism" (Sweeney 1996; Turner and Hurd 2001).

The idea of social unionism, which is sometimes called social movement unionism or social justice unionism, calls for the labor movement to coalesce with other social movements working for economic and social justice. This means that, in order to transform itself, labor must move to become more progressive politically. Social unionism requires that labor not only work to be more inclusive, but should concern itself with working class ideology in the U.S. and around the globe. Class consciousness can be developed within workers not only by an understanding of their own situation, but especially by learning about the experience of others who are struggling for their rights as fellow human beings (Hassan 2000). This concept is a huge return to the left for the American labor establishment, and at the local level, social unionism can be implemented in specific ways (see Figure 1). This table was created by sifting together the various ideas of labor scholars and labor leaders, and it attempts to discern the characteristics of business unionism and social unionism. 


\begin{tabular}{|l|l|l|}
\hline & Business Unionism & Social Unionism \\
\hline Social Welfare & $\begin{array}{l}\text { Benevolence for } \\
\text { membership only }\end{array}$ & $\begin{array}{l}\text { Assistance in broader } \\
\text { community }\end{array}$ \\
\hline Politics & $\begin{array}{l}\text { PAC money \& } \\
\text { endorsements; less } \\
\text { autonomy in decision- } \\
\text { making }\end{array}$ & $\begin{array}{l}\text { Coordinate members to } \\
\text { work for candidates \& } \\
\text { issues; input from rank \& } \\
\text { file towards consensus. }\end{array}$ \\
\hline Organizing Tactics & $\begin{array}{l}\text { Works solely within } \\
\text { traditional markets }\end{array}$ & $\begin{array}{l}\text { Creates liaisons with } \\
\text { religious/community } \\
\text { groups }\end{array}$ \\
\hline Women \& Minorities & $\begin{array}{l}\text { Minimal inclusion; few } \\
\text { leadership positions }\end{array}$ & $\begin{array}{l}\text { Programs to eliminate } \\
\text { racism \& sexism; women } \\
\text { \& minorities in leadership } \\
\text { positions }\end{array}$ \\
\hline AFL-CIO Policy & Loyalty to AFL-CIO & $\begin{array}{l}\text { Member of Change to } \\
\text { Win Federation }\end{array}$ \\
\hline
\end{tabular}

Figure 1. Differences between traditional business unionism and social unionism.

The diversity of labor unions (or lack thereof) is a problem, as well as the fact that change must come from the top down. Sweeney's "New Voice" program was meant to effect that change by making four proposals to all affiliates. The first priority is to organize the unorganized; this is sorely needed in order to reverse the decline in union membership. The second involves politics: there is to be no more across-the-board support for Democratic candidates-- they must first prove their loyalty to working families. The union locals are also expected to be involved in grassroots politics. Instead of just giving money to campaigns and endorsing certain candidates, workers are to become directly involved by walking neighborhoods and precincts, especially talking to other union members. Third, 
the community has become a priority: the leadership has vowed to bring new energy to local and regional central labor councils and to strengthen ties between local affiliates. The fourth involves the work site voice: due to the ever-increasing technology on the job, unions are to be partners with employers in worker training (Nissen 2002).

In the year 2000, the "new" AFL-CIO instituted another program, with the slogan "Organizing for Change, Changing to Organize" (Fletcher and Hurd 2000). While recognizing that this is a step in the right direction, Bill Fletcher and Richard Hurd argue that emphasis must be placed on quality as well as quantity. The labor movement must work to change the white, patriarchal nature of its leadership. In order to do this, they must reach the level of the rank and file members who are sometimes overwhelmingly racist and sexist. Fletcher and Hurd make three recommendations, which they see as necessary to accomplish these goals:

1. A strong educational component that enhances members' union skills while building a culture of organizing and inclusion.

2. Leadership development that specifically (but not exclusively) targets women and workers of color.

3. Support from the national union that includes advice, perspective, and (usually) resources.

(Fletcher and Hurd 2000).

This policy speaks to the fact that the U.S. workforce since the 1950s has seen a large influx of women and minorities. Unfortunately, these groups are 
over-represented in the part-time and/or temporary, or contingent, workforce, which is the fastest growing segment of the secondary labor market (Barker and Christensen 1998). This group, which stands to benefit the most from union membership, is also the most difficult to organize (Tilly 1996; Spalter-Roth and Hartmann 1998).

It has been shown that female and nonwhite union participation can decrease the wage differential in some markets (Wunnava and Peled 1999; McCall 2001). This has happened in the industrial private sector, where labor unions have traditionally had a strong foothold. One would assume that collective bargaining would do the same in other labor markets as well, but the inherent characteristics of these markets are preordained barriers to union organizing.

The problems that labor unions face in organizing the secondary labor market, especially those who are contingent workers, are many. Stability is the most pressing problem; traditional organizing methods do not generally work for a labor force that is transient and ever changing. The main gap in workers' ability to bargain collectively is the resistance of labor unions to allow the entry of parttime and/or temporary workers (duRivage, Carre, and Tilly, 1998). Organized labor could solve this problem and increase its bargaining power by installing reforms such as pre-hire agreements, multi-employer bargaining, and sectoral bargaining. Labor law needs reform, also, says Tilly (1998, p.265), in order to change "bad" part-time jobs into "good" part-time jobs. He speaks of legislation to 
ban or limit contingent employment and says laws must be enacted to extend benefits and supplements to workers who "fall through the cracks of current legislation".

Unlike the 1950s, the labor market is much more varied today, both in terms of the economy and the human capital involved. As Fletcher (2000, p.61) notes, "the workforce today is browner and more female". This fact alone cries out for renewed efforts to eliminate any trace of discrimination in the labor movement. This could be accomplished partially by coalitions with the civil rights movement; this is also an aspect of a return to social union status. But would the rank and file agree to such a proposition? Most locals which are predominately white and male probably would not. Racism is so entrenched and so endemic in our society that direct attempt at involvement with the civil rights movement would most likely fail. What could work, however, are attempts to educate the rank and file, in the hopes of eliminating the ignorance that breeds distrust and discrimination in our society.

Being on the sidelines of other social movements is subject to change with a revival of social union status. The tumultuous 1960s here and abroad gave rise to many social movements in Western society. Some scholars believe that the labor movement missed its chance by not becoming involved in the Civil Rights and other movements (Turner and Hurd 2001). In fact, the American Federation of State, County, and Municipal Employees (AFSCME) is one of the few unions 
which did engage in other social movements. This public sector union was responsible for bringing Dr. Martin Luther King, Jr. to Memphis for the Sanitation Workers strike in 1968, where he was subsequently assassinated. And unlike other unions, AFSCME has shown a steady and remarkable increase in its membership since its inception in 1936 (http://www.afscme.org/). But is this increase due to this particular union's social involvement, or due to the overarching changes in our economy? Since AFSCME is primarily a public sector union whose membership is service oriented, the growth of the service sector could be a causal factor.

How unions increase their membership and what they do for those members are the most crucial issues currently confronting the labor movement. Whether unions are willing to try new tactics for organizing and for working with management will be the deciding factor in their continued existence and growth. There is a trend, evidenced by the new AFL-CIO policies, toward social unionism. The argument, however, is how far this trend should or will take the labor movement. There is also a scholarly debate regarding rebuilding from the top-down vs. from the bottom-up. There are many grassroots labor organizations that have come and gone since the social upheaval of the 1960's. The workers themselves have sometimes led these associations, with the help of activists and/or social workers. Sometimes they form loose associations with area labor unions, and if these ties are successful, the unions will incorporate them (Tait 
2000). More often than not, however, these grass roots movements lose momentum and fade away over time. Like the fragmentation of the industrial economy, new workers' movements are too scattered and diverse for existing labor unions to grasp and maintain.

Labor is experiencing limited success using non-traditional strategies, such as changing the unit of organizing itself. Bonacich and Gapasin (2002) suggest two strategies: the first involves organizing the worker instead of the company. With this tactic, workers' centers are set up in the community, as a sort of clearing house to educate people about their rights in the workplace and to help them to defend those rights. An example of this strategy is the newly formed Working Today organization, based in New York City. Its current membership of 90,000 consists mostly of professionals, but its leadership hopes to include all workers in a union-type setting. It features a portable health care package, financial planning, legal services, and skills training for members, as well as a database of potential employers (Heckscher 2001).

The second method is to organize an entire sector of workers. The SEIU has a program with this in mind, called "Justice for Janitors", and many Living Wage campaigns across the country have already succeeded in bringing a better wage to city employees and those who contract with those cities.

The lesson learned here is that there can be no grassroots successes without the resources of already established unions. The idea of social unionism 
means that institutionalized unions must become more flexible and possibly more streamlined. They also must be willing to reach out to individuals and groups where they have never extended a hand before. The rhetoric of social unionism sounds very good on paper, but in practical terms, the logistics of pulling it off are incredibly tough. Many union members, especially white males, have been known to side with the right, both politically and ideologically, since the 1980s', the Reagan era. The hope is that through the inclusion of women and minorities, the momentum will be on the side of the left.

Even after all the changes Sweeney wrought in his ten years of leadership, there was growing dissent in the ranks. In July of 2005, the AFL-CIO national convention was supposed to be a celebration of the $50^{\text {th }}$ anniversary of the merger of the two federations. Instead, the focus was placed on a schism in the labor movement. A new federation emerged from the convention, initially called The Change to Win Coalition. Five major, progressive unions - the Laborers, Teamsters, UNITE HERE (the 2004 merger of two unions, the Union of Needletrades, Industrial, and Textile Employees, and Hotel Employees and Restaurant Employees International Union), UFCW (United Food and Commercial Workers), and SEIU (Service Employees International Union) - had issued certain demands to the AFL-CIO. These demands included, but were not limited to, more money for organizing, streamlining the Federation hierarchy, and an increased emphasis on rank and file education and involvement. When the 
federation expressed that they could not - or would not - answer to these demands, the rebelling unions split from the AFL-CIO to form their new coalition.

This new group wants more emphasis to be placed on organizing. The AFL-CIO has recently spent 20 to $25 \%$ of its budget on organizing, and its new goal is $30 \%$ for the $2005 / 06$ fiscal year. But the Change to Win Coalition wants no less than $50 \%$ of operating funds spent on organizing the non-union workforce. After supporting two failed Presidential candidates, the unions signatory to Change to Win see organizing as the only viable option in the fight to gain political momentum. Their reasoning is that, without a bigger percentage of the workforce, organized labor is simply not a political force at all. Some critics say that rebuilding the labor movement will take more than organizing and union density, however. The other requirements are "political and ideological change, rank and file education and empowerment, and a commitment to reinvigorating collective bargaining" (Master and Rosenstein 2005).

The Coalition believes that, by streamlining the hierarchy of the AFL-CIO, a huge effort can be mounted to "build a movement of working people that can confront and constrain corporate power in both the workplace and the community" (Change to Win website July 2005). Before the split, Teamsters President Hoffa wanted per-capita dues paid to the AFL-ClO cut by at least $50 \%$. Sweeney would only agree to a $25 \%$ decrease. At that point, the CtW officials wanted the ability to pick the 71-year-old Sweeney's successor, and they also 
asked for weighted votes for larger unions. When AFL-CIO officials would not concede to these demands, the CtW officially pulled out (Kutalik 2005).

In their mission statement they call for more budgetary openness and accountability, fewer executive positions, and want John Sweeney to step down as president. The irony in all this is threefold: first, Sweeney actually won his first election by making organizing the largest part of his platform. The second irony is that SEIU, one of the major players in the new coalition, is Sweeney's old union, where he served as president until he took the reins at the AFL-CIO. The third is that his slogan, "changing to organize, organizing to win" was morphed into the coalition's moniker, "Change to Win".

The coalition has since changed its name to the "Change to Win Federation" in an attempt to ensure that it is being seen as a real factor in the labor movement. The new federation has no legislative, international affairs, or political departments, as does the AFL-CIO. Their membership includes two new signatory unions, the United Brotherhood of Carpenters and Joiners of America, and the United Farm Workers of America; their numbers now total approximately 6 million workers, as compared to the AFL-CIO's depleted ranks of 8.5 million (Meyerson 2005). They are taking the best of the best of their member unions' strategists and are currently preparing to mount attacks on America's corporations. They have not yet and probably won't disclose the names of those corporations; it is thought that Wal-Mart is not yet on the coalition hit list, even 
though the UFCW has already mounted a huge media campaign called "Wake Up Wal-Mart" (Master and Rosenstein 2005).

As of November 2005, they have a constitution and newly elected officers, and they are still talking to the AFL-CIO regarding their local affiliates' relations with their state federations and Central Labor Councils. At first, John Sweeney had said that nowhere in the AFL-CIO's constitution did it allow room for the CtW affiliates to retain membership in their old CLC's. But, after considering the loss of revenue to the AFL-CIO's coffers, he has come to a compromise. He has proposed establishing "solidarity charters" where CtW locals could individually rejoin their state federations and Central Labor Councils. They would pay the same dues that they paid before the split, with a $10 \%$ surcharge in lieu of their AFL-CIO contributions made previously. If they agree to this deal, they will not have to set up their own duplicate state and local councils, thereby allowing even more time and effort to be spent towards organizing.

The Change to Win rift is being compared by some to the $\mathrm{ClO}$ split from the AFL in 1935. The ClO wanted to organize assembly line workers, 1.5 million of whom went on strike in 1934. The AFL actually fought against legislation throughout the 1930s (the National Industrial Rights Act and its subsequent replacement, the National Labor Relations Act, which set up the National Labor Relations Board) that gave workers the right to collective bargaining, while the more radical $\mathrm{CIO}$ unions organized the assembly workers. The $\mathrm{CIO}$ did not rejoin 
the AFL until 1955, when business unionism was the order of the day. Although Change to Win detractors claim that Wal-Mart is not the same as General Motors, the new federation definitely has retailers in its sights. The CtW federation fully intends to target retail corporations as fervently as the $\mathrm{ClO}$ of the 1930s pursued the manufacturing industry.

The work that must be done on the local level is the most daunting task that labor leaders have faced in the last fifty years. Our current low-wage, sagging economy will play a huge part in this task. Local unions may have many members out of work; these members can be idle and disgruntled over their situation, or they could use their time in more constructive ways. If local leaders are prepared, they will have the human capital to build the coalitions necessary for the next great social movement.

Are local labor leaders making a move toward social unionism, and if so, are they being successful? Indicators of this shift are inclusion of women and minorities, outreach in the broader community, and changing tactics of organizing and political influence. Definitive signs of success include both increase in membership and increased union market share. All these factors will be looked at in this comparative case study. 


\section{METHODS}

This study of business and social unionism uses a comparative case study approach, as outlined in the text Research Design (Creswell 2003). These case studies employ some quantitative but mostly qualitative data to analyze the extent of change that recent AFL-CIO policies are bringing about. National longitudinal trends of the last twenty years show the rate of change in female and minority membership. These data were first gathered by the United States Bureau of Labor Statistics in 1983, so longer-term trends are not accessible. A comparison of national and local data is not feasible at this time, because only one of the three local unions made their demographic data available.

The qualitative data are much more revealing. I interviewed seven officials in three different types of local unions in a small Midwestern city. The locals and their officials are made known only by type: craft, service sector, and public sector union. A letter was sent to select officials of the three types of unions to gain entré. Time and place were set by phone, according to their convenience. Although it has been recommended that qualitative scholarship consists of at least eight interviews (McCracken 1988), this was a most difficult task due to the officials' hectic schedules. I made sure to interview at least two officials in each type of local, to insure that the data were not one-sided.

The interviews lasted between thirty minutes and one and one half hours; the average interview was fifty minutes long. This was quite adequate to answer 
the interview questions as written, and also allowed enough time for comments and questions. The overall structure of the interviews was guided by the text Qualitative Interviewing (Rubin and Rubin 2005), which was also consulted in the analysis. The respondents were asked at the outset whether the interviews could be tape recorded; it was explained to them that their identities would not be revealed, and that no one else, other than myself, my thesis committee, and a typist would have access to the tapes and transcripts, and that they would be stored under lock and key.

The interviews were then transcribed by the typist and the excerpts seen here were taken from those transcripts; in all they totaled 56 pages. The transcripts were single spaced; the shortest was 4.5 pages long, the longest 11.5 , and the average was 8 pages. In very few instances did I find it necessary to refer back to the tapes. The officials were very forthcoming and only two wanted to speak off the record. The subjects discussed off the record had to do with future projects and/or organizing campaigns which they did not want to jeopardize or compromise.

The main goal was to speak with the organizers of these locals, but also to interview the president or business managers, in order to gauge the direction in which the local is headed. Since two of the three locals are still affiliated with the AFL-CIO, an attempt was made to determine just how much AFL-CIO policies affect these locals. The service sector local, having just recently left the AFL-CIO 
Federation, is now part of the Change to Win Federation. All of the union officials were asked about their opinion of the split and asked to comment on any changes they have seen or expect to see in the near future.

Although most union officials are elected in a true democratic fashion, much of the planning and direction of the locals is hierarchical. The locals take direction from their regional office, which takes direction from the national or international office. This is where the link to the AFL-CIO is located. In order to determine how policy is filtered down through these channels, I inquired how locals interpret national policy, the end result of this chain of command. Since the bureaucracy of labor has been critiqued as a stumbling block in the road to rebuilding the movement (Nissen 2002), this is an important aspect of the study.

Interview questions attempted to discover the awareness and the willingness of local leaders to realize social union status. If local leaders were aware of the differences between social and business unionism, questions were aimed at discovery of the involvement of the rank-and-file. Data were sought that show participation rates of the members in any new programs that are indicative of social movements, i.e. did any members volunteer to help the recent local Living Wage campaign, and are any members involved in the Fairness campaign? Although the locals' involvement as a whole was commented on, no data were available that quantified the rank and file involvement. In order to get 
at this information, the rank and file would have to be surveyed, which would make an excellent basis for another study.

The inclusion of women and minorities was also a major topic in the interviews. An attempt was made to gain data, if available, on the rank and file as well as local leaders. Another question, which helped in determining social union status, was asked of these leaders to determine if there was any type of outreach to the broader community, in terms of social welfare or inclusionary policies.

Other indicators of social union status are related to political involvement; traditionally, unions have endorsed Democratic candidates, donated money to their campaigns, and urged their members to vote for them. But both Sweeney and the Change to Win federation recommend that they look at candidates in a non-partisan fashion, backing only those who support the labor movement. A social movement includes intense political involvement. Are these locals coordinating efforts to help candidates in recent elections, and to push labor issues, such as Right to Work and prevailing wage, in local and state government? More to the point, how are these decisions regarding issues, endorsements, and campaign contributions made? Committees as sole decision makers are more indicative of hierarchical organizations, therefore locals using this system would tend toward business unionism, at least in this aspect. A more consensual decision process, involving more of the rank and file, would indicate a trend toward social movement unionism. 
Another other issue is social welfare. Are locals reaching out to organizations other than themselves to help with problems in the broader community? And instead of just providing their targeted workers the benefits of union membership, are they broadcasting those benefits throughout the community?

And finally, the organizing tactics used by locals serve to demonstrate the amount of their enthusiasm for gaining social union status. Do they simply target traditional companies and sectors in their region? Or do they work with the community at large and groups within that community (such as religious or community centers) to organize workers?

This research has made an attempt to discover how much, if at all, local unions in a small Midwestern city are willing to present themselves as socially progressive entities. The stigma of being branded "leftist" or even "liberal" has increased greatly over the last two decades by the right's shrewd use of the media. Many rank and file union members have succumbed to the rhetoric of the right, even while they pay dues to organizations with roots in socialist ideology. This paradox, if left unresolved, will contribute even more to the decline, and possibly the demise, of the American labor movement. The awareness of local leaders is key in swaying the opinion and behaviors of the rank and file. 


\section{ANALYSIS}

The five different characteristics in this study, Social Welfare, Politics, Organizing Tactics, Women and Minorities, and AFL-CIO policy, gave an indepth view of the differences between local unions, not only in their practices, but in their makeup. The questions asked in the interviews were broken down into these major categories, and subcategories also became apparent in the interviews, with some being unique to one type of union, and some being similar in all three types of locals. The themes that emerged within the first category were the benefits of union membership and whether or not the local performed any work in the community, with or without the alliance of other groups. The second category, regarding politics, revealed the similarities and differences of how the process of endorsements and contributions were decided upon. When discussing organizing, the locals were all different enough in the nature of their industries to provide very different methods of gaining new members and servicing existing ones. The same sub-themes emerged when discussing race and gender issues; the racial and gender makeup of the membership of all three unions is very different, due to the types of jobs involved and the fact that some are "non-traditional" for women and minorities. The last category, where the respondents discussed their union's relationship to the AFL-CIO, brought out 
issues of the schism in the "House of Labor", and three different reactions to that split. 


\section{Improving Social Welfare}

The answers to interview questions were revealing in both their differences and similarities between different types of local unions. For example, in answer to the questions regarding the improvement of social welfare of both the rank and file and the larger community, all union officials agreed that the main improvement they provided was the increase in benefits and wages for their members. This not only improves their workers' lives, but it also takes a burden off of the community's responsibility to provide social services to its citizens. Another extremely important result is that, as the old saw goes, a rising tide floats all boats; the historic impact of labor unions is that working conditions and wages have been improved across the board in the last century.

Some of the benefits to the rank and file included not only wages, but also strong health insurance policies, retirement pensions, safety on the job and job security. Although the last item is used in corporate propaganda as an argument against unions, by telling a non-union workforce that bringing in a union will surely cause that company to close its doors, the union officials interviewed here argued that their members were more secure in their jobs because of their efforts.

One example of the protection of job security came from the local craft union. Since craft unions have traditionally and even currently leaned more toward business unionism, one of their organizing/survival tactics is market share 
protection. They accomplish this in a number of ways. The first and foremost, historically, was protection of trade secrets. In a world where information is increasingly more widespread and accessible, however, this is no longer possible. The modern trade union will present its workforce today as the most knowledgeable and well-trained by providing the most extensive and rigorous apprenticeship and training programs.

Another tactic well used by the trade union is protection of market share by investigating non-union jobs and training. This can reveal poor or shoddy work, which on many occasions can endanger the customer and/or the general public. The trade organizer had photographs in his possession of a non-union jobsite where the workmanship was so shoddy that one had to wonder why and how it passed inspection. It was his job, then, to bring this work to the attention of local authorities, the media, and the taxpayers, who ultimately paid for the job since it was a state funded project. But in bringing this particular job to the attention of the state's Chief Inspector, he was told that "we both know that on any project of this magnitude there are always some code violations." The problem of understaffing was also endemic to all local unions; in this case, the organizer has not had the time to follow up on such violations. He wants to prosecute, but does not have the time or the resources.

He also spoke of a local private college/technical school and their training methods. These were revealed by an out-of-work union member who went to 
work there as an instructor. The union "mole" found out that trade students were being charged an exorbitant amount of tuition and their program was very similar to a union apprenticeship, in that most of the training was on the job, but also very dissimilar from the union's apprenticeship, in that the training was extremely short-term. So in essence, they were paying the school for their jobs, and working for non-union contractors who were getting free labor. When he talked to someone at the school, he was told:

"'Yeah, what we do...is take a guy and put him through 1820 days of training and then do a job placement.' Through our conversation I found out basically they were providing people to the [non-union contractor's association]. Just cheap help, and they weren't apprenticeships at all but it was also very, very expensive."

According to this official, a representative of the college in question, at a local trade meeting, sold the program as follows:

" 'We have this terrific program...that is like a boot camp for [tradesmen]. It includes about 4 weeks of intense training. One day a week for about 9 weeks and you have a [tradesman]. '

After further investigation, the union "mole" was able to uncover exactly what was going on:

"The first week there, he found out that it was nothing but a money mill. So, he would go home at night and he kept a log of everything that transpired and he would email it to me. I went out there and interviewed the students as they were going in, to let them know that it was a scam. They were charging those people, with no aptitude testing at all, $\$ 10,700.00$ a piece for this make believe education. Once they got their hands on the money they didn't care if they made it through the program or not...I found out 
that this was going on on campuses all around the country, at four different locations."

The official took this information to the national office of the AFL-CIO Building Trades, as well as local TV and newspaper outlets. The college in question closed its doors shortly thereafter. The official modestly stated: "so that is one way we have been an effect on the community."

The service sector union officials both spoke of their policies of "mass servicing", where they go to jobsites and provide help with problems on the job and/or questions about member benefits. This is a new effort to make union benefits more accessible to the rank and file. They also spoke of their efforts to educate the membership about workplace and political issues.

The officials in the service sector union spoke of their work with civil rights, community, and religious groups. This is a vital part of their status in adhering to social movement unionism policy.

"I am glad that you are focusing on this idea of social movement unionism as opposed to business unionism - it is important to us here. We are always looking for ways to empower our shop stewards to energize our membership. It is hard because of the challenges of the nature of our industries. We are committed to making that real.

We are known as what you call an active local that participates in public activities, rallies, demonstrations, letters to the editor, web-based communication...Working with officials, we participate in a lot of community organizations. We are active in the NAACP, in the Latino community, in women's organizations.

We take an active role in the issues of the day. One thing we are proud of locally,... we took a stand some years ago for Fairness 
\{the local GLBT rights campaign\}. Not that our members aren't all over the board as to social issues, but we think discrimination in the workplace is wrong...The workplace is for everybody, not for anybody to excluded.

We believe strongly in labor, community, and religious coalition. We work with the civil rights community, with the religious community, not only on labor issues, but also on issues that are important to other communities. That is what solidarity is."

The organizer in this local was able to shed even more light on the union's

motivations for working with community groups during plant organizing efforts:

"It basically starts with [the workers] signing a card, but...we don't just work with the workers, we try to work in that community with the groups as well. Civic groups, church groups, community groups...so while we are educating the workers, we are also trying to educate the community groups as well because the workers at some point are going to need a lot of support from the community. Now one of the major groups that I have found to work with, and they go hand in hand, is labor and civil rights. ...Labor and civil rights are two movements but one goal. Our ultimate goal is for workers to have dignity and to have justice on the job, and if a worker is to be fired or whatever then I feel there has to be just cause."

The public sector official also commented on the history of their international union's involvement in the 1960s era civil rights movement. This proud tradition continues today with the local's involvement in civil rights and other organizations in the community.

"We are involved with a lot of coalitions. For instance, we worked with Jobs With Justice for the Living Wage Campaign. [State residents] for Single Payer Healthcare. So...that gets your name out there, working with different civil rights organizations, different religious organizations...lots of times union issues are social issues of life as well. ...from a labor perspective, you have to form these coalitions..., and definitely try to assist each other...." 
The issue of community involvement held very different meanings for the locals. The trade union saw its role as more proactive in regards to its market share and trade protection and integrity. The service and public sector unions are more active in their community, which serves as positive public relations measures on their part.

\section{Political Issues and Candidates}

The similarities between locals, in regard to political issues and candidates, were that all three types of unions had Political Action Committees. They all took voluntary contributions from members of the rank and file and used the money to contribute to political candidates and lobby for legal issues relevant to labor. The differences between locals resided in the decision-making process when it came to the endorsement of political candidates.

The local trade union has a Political Action Committee, which interviews local candidates regarding their stance on labor issues. The regional Central Labor Council also interviews candidates and reports to the local's committee. The PAC then decides which candidates the local will endorse, and if and when there will be contributions to those candidates' campaigns. A list of endorsed candidates is published in the local's newsletter just before Election Day. 
In the service sector union, partly because of the "size and scope of the people [they] represent," the decisions are made by an executive board that interviews candidates and subsequently makes endorsement and contribution decisions. The rank and file does not have direct input, except when "politically active people may have recommendations that they bring to the executive board... Where decisions like that become more centralized because we don't have the same sort of smallscale relationship, they are more lateral. It is not necessarily the best way, but I think it is the only way that can work for now."

The public sector union was the most radically different in this regard;

political candidates are invited to a forum, at which they are asked to speak and answer questions. The audience at this forum is made up of interested members of the rank and file, who then make the endorsement decisions for the local.

"We send out questionnaires and those [members] that respond to the questionnaires are the ones that are invited to the forum... Once they are invited they pose questions to the candidates, 'what about a living wage? What about unions, what are your positions?' After everybody is gone, we sit down and debate. ...those that do have a record that you can look at...here is what they said, but here is how they voted. ...At that point we make a decision to either endorse, or no recommendation or no endorsement.

...we also try to tell them that we are the only employees that get to have a say in who our bosses are. Don't you think other employees would kill for that?"

In any of these locals, those members who want to have their say will be heard, but the union that granted the most autonomy to its members was clearly the public sector union. The trade union is conforming to its traditional 
hierarchical roots. The service sector union makes decisions for its members because of the large numbers of its rank and file; consensual decision making is not the most efficient process.

\section{Organizing}

The organizing tactics of the local trade union tend to change with economic trends. When work in the local's jurisdiction is plentiful, "bottom up" tactics are put to use. This involves going to the workers themselves, with tactics such as "salting" where union members go to work for non-union contractors and try to persuade their workers to come into the union fold. This method is most effective when the best and brightest of the non-union contractors' workforces are targeted and successfully recruited away. As anyone might realize, though, this tactic does not work well if there are many existing union members on the out-of-work list. This local also uses the traditional method of going after an open shop, or non-union contractor, and persuading all of its employees to go union. This is also accomplished by union workers -as surreptitiously as possible- going to work for non-union companies, and then convincing their co-workers that going union is a good idea. The organizers may also talk to the workers off the jobsite, meeting with them at the union hall or elsewhere. This method eventually calls for a company vote in order to obtain bargaining rights for the workers in 
that shop. Again, this is not necessarily the most-used method when work is slow.

During slack times, the trade local uses what they call "top down" organizing tactics. They try to approach non-union contractors and sell the fact that the union can provide a more educated and highly trained workforce, thereby cutting production costs for the contractor and improving services to the customer. This also includes a new public relations push on the part of this local, to educate the end user about the benefits of a unionized workforce. The organizer attempts to attend as many local industry, business, and government meetings as possible to tout the advantages of union labor, and to improve its image.

"I will be making...sales presentations. I am going to get some printed material and then start calling on not only open shop contractors, but also calling on businesses. Then from those businesses, do membership development, trying to avail them of our services, and let them know what we really do here. ...I think we have been labeled as thugs and kneecap-breakers and things like that. That's just not the way we are. So, it will be more like a sales presentation than anything. And I hope to engender some good feelings in the community instead of all the negative stuff. ...businesses in this country spend hundreds of millions if not billions trying to bust unions. And that is sad. Just think if they donated all that money they are using trying to bust us. We wouldn't have to be worried about...the right to work law."

The organizing tactics used by the local service sector union included a public relations push to reveal negative workplace issues. This union's international has mounted a campaign against a national retailer, complete with 
press releases and a website. On the local level, one of the officials likes to find what he calls a business's "pressure points."

"In order to get an employer to change his mind about unions you have to do three things. First, you have to make him mad; two, you have to create a problem for them; and three, then they have to look for a solution. So we are often finding places where they are being bad, or hypocritical, or vulnerable, in a variety of things. Bringing that to light, filing with an agency, maybe a law suit, it might be a handbill, whatever it is, in order to make them respond. If you are making them respond, then they are playing your game."

And another tactic during organizing campaigns is home calls to potential union members. This is a tried and true method of persuading workers to vote for the union (Lopez 2004).

The public sector union is still working through the aftermath of a city/county merger, which has proven to be a huge problem to the local. The two entities had different pay scales, different representation, and in some cases, different unions. Occasionally, this local has to fend off other, rival unions that approach their workforce with seemingly better offers of representation. This tactic is called raiding, and is seen as one of the many forces of union decline. The Change to Win Federation has taken a definitive anti-raiding stance; they equate union solidarity with union strength, and see raiding as pre-emptive to solidarity across the board.

None of the locals seem to favor old school tactics, such as strikes and picket lines, except as an extreme last resort for bargaining. In fact, the trade 
union officials were worried that the President of the Carpenters' union, which is

now signatory to the Change to Win Federation, is using those tactics too much:

"He won't flex or bend or waver. He is going to do this, that, or the other. $\mathrm{He}$ is making things rough around here. He really is. In [town] some of his decisions are alienating some of our users and customers, picket lines and things like that.

[A large local company] is the only customer that has got a product they can sell. And the Carpenters have a picket line wrapped around this job over here. They are also hand billing their office building... and their stores in town, so that gives them a great deal of heartburn, which makes it rough for us. Will the next job go good, I don't know. [The company executives], they don't like that, especially during the Holidays. ...the decisions he makes, they do affect us. They have adopted a very aggressive organizing policy and they pay people $\$ 8.00$ an hour and they don't care where they come from, to carry water on these picket lines. I sympathize with them. It may be a good tactic, but the customers don't like it. There are mixed emotions on the pickets. Are they effective? If you have control, they probably are, but we don't have a smattering of control anymore. So I think they are more a pain in the ass than they are effective. I think partnership works more than aggressive involvement."

With these organizing tactics, all three unions are striving to increase their membership. The differences lay in the aggressiveness of the tactics and the resources each local earmark for the jobs. All of the officials I interviewed either stated outright or at least implied that not enough resources were given to organizing. 


\section{Race and Gender}

Overall, national trends have shown that African Americans have a higher union density than whites (see Figure 2 below). This has held true for at least the last 20 years. The only group that showed an increase or even held steady in union density at any time in this period was women. Their slight increase of .4\% between 1988 and 1993 is most likely the result of the huge influx of women into the workforce in the last quarter of the $20^{\text {th }}$ century.

\begin{tabular}{|l|l|l|l|l|}
\hline & $\mathbf{1 9 8 8}$ & $\mathbf{1 9 9 3}$ & $\mathbf{1 9 9 8}$ & $\mathbf{2 0 0 3}$ \\
\hline TOTAL & 16.8 & 15.8 & 13.9 & 12.9 \\
\hline Men & 20.4 & 18.4 & 16.2 & 14.3 \\
\hline Women & 12.6 & 13.0 & 11.4 & 11.4 \\
\hline White & 16.0 & 15.2 & 13.5 & 12.5 \\
\hline Black & 22.9 & 21.0 & 17.7 & 16.5 \\
\hline Hispanic & 16.0 & 15.1 & 11.9 & 10.4 \\
\hline Asian* & ---- & ---- & ---- & 11.4 \\
\hline
\end{tabular}

*No figures reported until 2003.

Data from the U.S. Department of Labor, Bureau of Labor Statistics News, 1990, and www.bls.gov. 
When looking at specific unions, the membership varies in color and gender, depending on the type of worker represented. The membership of the local trade union is overwhelmingly white and male. Their minority census, dated January 5,2005 , reveals that out of approximately 1750 construction members, a mere $4.4 \%$ were African American, and only 3.9\% were women (see census below).

\begin{tabular}{|l|l|}
\hline Black Males & 71 \\
\hline Black Females & 6 \\
\hline Caucasian Females & 60 \\
\hline Italian Males & 1 \\
\hline Italian Females & 1 \\
\hline Hispanic Males & 7 \\
\hline Pacific Islanders Male & 5 \\
\hline Greek Men & 1 \\
\hline Arabic Men & 3 \\
\hline American Indian Female & 1 \\
\hline American Indian Male & 3 \\
\hline Eastern European Male & 1 \\
\hline Asian Male & 1 \\
\hline
\end{tabular}

Local Trade Union Minority Census. Total Construction Membership N=1750 1800, including 275 Apprentices. 
Although hard local data were not available, one official at the service sector union estimated that approximately $50 \%$ of their rank and file membership was either female or minority. The large majority of their minority population is Latino, in a region where the Hispanic population has increased exponentially in the last twenty years. They also represent a huge immigrant population: "at one of our plants here in town, members speak 14 different languages."

Another interesting fact was brought to light; since these service sector jobs have a high turnover rate nationwide, at least $40 \%$ of this union's membership is under 25 years of age. This is significant because "in some respects we are the first face of a union for a lot of America's young people."

The majority of the public sector union's local membership was reported to be female, although no figures were given. And this membership was also presented as over $50 \%$ minority, mostly African American, but including a large recent influx of Hispanic immigrants.

"And probably as far as the racial makeup and total of our local it is probably 50 to $51 \%$ people of color and $49 \%$ white. So it is pretty evenly balanced but, by and large, the majority of our members are female. That plays a big part with issues regarding childcare, FMLA, domestic violence; we have quite a few incidents of that. And we do have a women's section by way of our international that deals with issues specifically pertaining to women. They also have a section that deals with people of color. We are a very diverse group." 
What is possibly more important to each local than the rank and file racial and gender makeup is the diversity of its leadership. At the trade union, all the officials I spoke with were white, but one was female. At the public sector union, one official was a black female, and the other was a white male who represents a mostly female, racially diverse rank and file. The service sector union officials were a white and an African-American male. The Change to Win Federation, and most progressive labor scholars agree, that union leadership must become more diverse if unions are to survive and thrive. 


\section{AFL-CIO Policy, the Change to Win Federation}

All three local unions were in agreement that AFL-CIO policy has had very little effect at the local level. Their thoughts on the matter, as far as causes for this, varied, however. Some saw the AFL-CIO as fairly stagnant in its recent programs and policies.

"There were some good years in there with progressive activity and increased focus on organizing. It is the nature of the organization, which... depends a lot on consensus that left bigger and more active unions held back and slowed down by organizations that didn't want to be active or progressive."

It is also evidenced by the fact that almost none of them knew that Sweeney's original aim was for more organizing.

The trade local is still affiliated with the AFL-CIO, and although its officials expressed a very negative opinion of the split, they admitted that the Change to Win Coalition had some legitimate complaints.

"They talk about solidarity and things like that, but you know a fractured organization is not much of an organization, and they have split the House of Labor, and that hurts all of us. I think Sweeney's policy is good. I believe he is committed to organizing which of course is our life's blood, organized labor. Now could he be more efficient? Sure, but I don't think that's bad policy. I think that is a result of the political climate in this country, among other things.

They have issues; bring it to the forefront and take care of it in-house. The split did nothing, in my estimation, nothing for organized labor and has caused a lot of problems.

My understanding of it was they wanted to eliminate some of the hierarchy in the AFL-CIO. And that is where I see some legitimacy in it. The organizing issues were, as I understand it...they felt that not enough was being done to go out and organize un- 
represented workers. They wanted to take money away

from...service reps out servicing the membership and put in the organizers, and I agree with that. More money needs to be spent on organizing."

It was also very revealing when one official, who still works daily in the trade, said that the rank and file knows very little about the split. The office that this official holds is primarily a figurehead position. The main thing that those in the field knew was that the carpenters were part of the new coalition.

“...people out on the job say...'do you believe about the carpenters breaking off?'...they can't believe they did it, but they don't really care that they did it. There was a whole bunch of them [carpenters] out at the...job; I mean a whole load of them. This was when it was coming about. It was something that was sort of a no-no to even bring up to each other. ...I mean, they weren't really nasty about it. But they didn't really want to talk about it, and you didn't even want to ask them. People knew that they were doing it, but it...just...didn't mean nothing to most of 'em. They just didn't say anything."

The officials at the service sector union held positive opinions about the split, this due in part to the fact that they are part of the Change to Win Federation. They commented that the change would surely be good for organizing and rebuilding labor, although they intimated that there had been no substantial changes as yet at the local level.

"I think the main thing, or one of the things, that the AFL-ClO says, is that they feel like we need to keep doing more political stuff, and let's face it, the last two presidential elections we pretty much did the same thing the same way. We have ended up with the same results, and pretty much that is...getting beat like a drum.

I think one of the things that Change to Win wants to bring to the top of the rim is organizing. Because the labor movement, in 
our estimation, is dwindling, and the only way you are going to get stronger is to increase the membership, and the only way you are going to increase the membership is through organizing. So I think the Change to Win is saying that the importance should be to put more money into organizing to make us stronger, and now when we vote, we got more members, and we educate them, and then we have the numbers to win."

The public sector local is still affiliated with the AFL-CIO, and the official there had mixed feelings about the split. This official was, however, in favor of "Solidarity Letters" (Solidarity Charters), a method of bringing locals back into the fold. In these charters, the AFL-CIO asks the local entities to remain loyal, regardless of their international affiliation.

"Your international may be out, but your local wants to stay within the local Central Labor Council, and it came from Sweeney to say...we will figure it out. He said it not too long after that convention, that they were going to work on how are we going to set up a dual structure... [so that] you can remain in this group even though your international is not part of the national AFL-CIO."

Although all local union officials agreed with the concepts that the Change to Win Federation is trying to actualize, those whose unions remained loyal to the AFL-CIO complained that a split was not the proper way to accomplish those changes. They believe that solidarity is more important than radical change, even when faced with the disastrous effects of the overall decline in union membership. 
A recurring theme became apparent during the interviews; this was the apparent apathy and lack of knowledge of rank and file members, and to some extent the union officials themselves. It has happened across all types of unions, including the service sector and public sector locals studied here. This was most obvious and an increasingly impervious problem in the trade union, however. The craftspeople in this union traditionally have been more involved in union activities, but are becoming less involved and more indifferent to their plight as union members.

"I honestly feel the whole union thing is going to hell in a hand basket... [because of] peoples' attitude toward it. At our union meetings, we were averaging a couple hundred a month... the last 4 or 5, we've had 40,50, 60 people. Nobody gets up and asks anything, nobody says anything, they just listen and leave. It's over in an hour... they just don't care. As long as they get that paycheck, they don't care where it came from or how it got there.

What's bad is when we ask people to get involved. Everybody says, 'what has the union done to help me'; well, what have you done to help the union?...Anything you do, you have the same 10,12, 15 people that you see at every volunteer involvement.

We've tried everything: begging, pleading, shaming. I wish we could get some more education out there on the union, and I don't know how to do it."

When looking at national trends, the building trades are a prime example of the decline of business unionism. As of 2004, union density in the building trades hit an historic low of $14.7 \%$. This is a continuation of the decline measured between the years 1973-2002, where union membership in the United States 
building trades went from 1.6 to 1.2 million. In the same period, non-union building trades jobs grew from 2.5 to 5.5 million. In the space of 19 years, union density in the U.S. building trades went from $39.5 \%$ to $17.4 \%$ (Ehrlich and Grabelsky 2005).

Looking at one specific trade shows an even clearer picture of this devastating decline. In the years between 1965 and 1990, the United States electrical construction workforce more than tripled, going from a total of 200,000 to 550,000 . But the International Brotherhood of Electrical Workers' membership remained static at 140,000 . Thus, union density in this 25 -year period in the electrical trade declined from $70 \%$ to $25 \%$ (Ehrlich and Grabelsky 2005). 


\section{CONCLUSION}

There are three questions on the mind of nearly everyone involved in today's labor movement, including its corporate and political enemies. The first and foremost is, will unions survive? The multifaceted answer is by no means easy, since there are so many internal and external pressures bearing down on the $21^{\text {st }}$ century movement. The crux of the movement, worker solidarity, has never been so fractured and inert. Union detractors are quick to note the steady decline of the movement as signs of its decreasing relevance and eventual disappearance. But if today's workers are finding it difficult to support their families, and America's working families are, on the whole, not as financially well off as were their parents, does that not make the labor movement as necessary as ever?

The second and third questions depend on an affirmative answer to the first question. If those involved with the movement are right, and the answer is yes, then who is best prepared to rebuild the movement? And how will they do it? It does seem that those unions more involved with other social movements are more poised to rebuild, as rebuilding is by all means going to require a grassroots effort. But those unions also need adequate resources to combat the 
ever-growing power of corporate hegemony. They will not only need to use technology, but also human capital.

Exactly why are the labor organizations with the characteristics of social movement unionism better equipped than those who lean more towards business unionism to rebuild the labor movement? This question can be answered more easily by looking at the five characteristics of figure 1. First, a union that concerns itself with the welfare of the larger community in which it is located builds more community awareness of the existence and benevolence of labor unions. A union which provides benefits only for its members, as in the case of those operating under the methods of business unionism, isolates and insulates itself within the larger community.

When looking at the second characteristic, which looks at how unions influence political decisions, it can be argued that those unions with a social movement bent are more successful at getting their members involved in the process. Business unions are more inclined to make hierarchical political decisions regarding candidates and issues, thereby cutting members out of the decision making. Social movement unions would typically make these decisions on a more consensual basis, which automatically includes and empowers a larger percentage of the rank and file. Consensual decision making, when it comes to making political decisions, is much more conducive to member involvement. If the process is strictly hierarchical, the rank and file is more likely 
to leave the decisions totally up to the persons in charge, and less likely to speak their minds and become involved in the process. And member involvement is key in the rebuilding process.

Certain organizing tactics are proven more successful than others, and social movement unions are choosing those more successful tactics. Grassroots efforts should prove to be extremely fruitful for unions in the near future; liaisons with civic and community groups build not only community awareness but community support. A union goal should not only strive for solidarity amongst and between unions, but also solidarity in the community. For companies who are not good corporate citizens, community solidarity would have the effect of bringing pressure to bear from within and from outside the confines of the corporation. Issues such as discrimination and the environment could and should be addressed so that neither workers nor corporate neighbors are exploited by employers.

Business unionism is not conducive to grassroots movements in that it does not allow for widespread involvement of the community. When only members are involved, other groups and individuals are excluded, and the union loses the empowerment that inclusionary policies can bring. Coalitions are much more powerful than a single voice in the wilderness, as big business has found out through mega-mergers and multinationals. 
In the past, racial and gender discrimination have been very functional for corporate profiteering; women and minorities were relegated to lesser paying jobs, and even today the jobs that women traditionally have held are lower paying than traditionally male jobs. Another advantage, especially with racial discrimination, comes with the competition for resources. When one group of workers is pitted against another, business stands to gain with decreasing wages, which has happened time and again with immigrant workers in the United States. Negative emotions and energy are also deflected away from corporations and toward the marginalized groups. If labor unions were to address issues of racism and discrimination, they would strengthen solidarity not only within, but also in the broader community; social unionism has an inherent bent toward this goal.

When exploring national labor policy, it becomes apparent that the Change to Win Federation has a definite advantage over the AFL-CIO in many regards. The public conception of the AFL-CIO is one of mob-connected "fat cats"; old white men drinking cocktails and chomping on cigars. However far from the truth this is, it is not an image which workers are likely to respect. CtW, on the other hand, has a unique opportunity to invent its own public image, through the shrewd use of media spin. With the majority of their resources going towards organizing, the unions in CtW will have the ability to bring new, innovative ideas to the movement. And without the bureaucracy of the AFL-CIO, CtW will have the 
flexibility to build the momentum that will be necessary in the fight for the hearts and minds of workers.

The three types of unions in this study have different characteristics in regards to business and social movement unionism (see Figure 4 below). Those who have more of the social movement characteristics do seem to be more prepared to aggressively pursue the rebuilding of the labor movement as a whole. The union with the most business characteristics is not ready to become a dynamic player in the reconstruction; although it may be involved and certainly will stand to benefit from a union resurgence, its gains will be parochial in nature and will not be as far-reaching as those of the other unions.

\section{Craft Union}

The craft union analyzed in this study seems to operate strictly by the premises of business unionism. Their interests in social welfare rarely extend out into the community at large, although their efforts to increase members' wages and benefits indirectly support the community. But with the exception of a benefit held during the Christmas season, their outreach to other groups is almost nonexistent. This local's attempts to secure market share by trade protectionism can also be seen as a community benefit, but the motive behind the work is strictly in the union's self-interest, and any advantage to the community is purely accidental. 
When making decisions regarding political issues and candidates, the craft union tends toward business unionism. The decisions, made by committee, are hierarchical in nature. Although members who speak up are given a chance to be heard, the decisions are made by officials on the political action committee. And very few rank and file members are currently even asking to be involved in this process.

Although the craft union was eager for a larger organizing budget, their affiliation to the AFL-CIO puts constraints on the percentage that they spend on organizing. Sweeney's original push for more organizing capital unfortunately got sidetracked by the entrenched bureaucracy of the powers that be. If locals are not allowed greater resources for organizing, they will not be able to regain their market share, much less participate in the greater goal of rebuilding the movement.

Although one official in the local craft union was female, this seems to be a token position, as her role in the day to day workings of the local is not extremely important. The racial and gender makeup of the rank and file of this local is not at all diverse, although the official who released the figures was of the opinion that the trade had made quite a bit of progress since the 1970s. Much more work needs to be done in this area, not only recruitment of women and minorities into the union, but working to eliminate racism and sexism in the rank and file. 
The trade unions, with the exception of the Carpenters and Laborers, have remained steadfast in their loyalty to the AFL-CIO. Judging by the craft local examined here, there needs to be increased member involvement in order to regain their loss of market share. This increase would necessarily be of a voluntary nature, due to the lack of increase in organizing funds. In an era where families are overscheduled and overburdened with work and activities, and/or spending massive amounts of time addicted to popular culture distractions, this is a daunting problem.

\section{Public Sector Union}

The public sector local has proven its social movement status in the arena of social welfare; although it has been preoccupied with the city/county merger, it has been progressive in its alliance with civil rights groups and also in the bringing of women's workplace issues to the forefront. It has improved the lives of its own members by the traditional means of negotiating for better wages and benefits, but through its direct involvement with the Living Wage campaign, it has worked to benefit others in the community. This local also has strong ties with area churches and routinely performs charitable work through them, benefiting people other than those in its own rank and file.

The consensual nature of its political decision making is the most progressive of the three unions studied here. The fact that many of the public sector's members work in government offices naturally foments more rank and 
file involvement in politics, which tends to facilitate a more egalitarian process. When decisions have such direct impact on workers' lives, they are more likely to take time to give their input. This is an ideal practice of social unionism.

But because of its current de-emphasis on organizing, the public sector local must be relegated on this item to business unionism. This is definitely not intentional, but a direct result of expending all available resources dealing with the city/county merger and other issues such as raiding attempts by outside unions. Although this union has traditionally been directly involved with the civil rights movement locally and nationally, evidence of strong recent involvement is scarce. This factor will surely be soon to change when internal matters are dealt with and put to rest.

The public sector union gains back its social movement status in the area of diversity; it has always represented a very diverse group, from "sanitation engineers" to teachers' aides. These are the thankless, traditionally low paid jobs that are relegated by the legacy of discrimination to people of color and women. If the public sector union is to be even more successful in its social movement status, it will bring back the discussion of pay equity to the forefront of issues in America.

Remaining with the AFL-CIO relegates the public sector local to business union status; the officials here were positive about the solidarity charters, however. This is an indication of their willingness to support the progress that the 
Change to Win unions wish to bring about. But they are steadfast in their belief that solidarity is more important than fluid and progressive change, no matter what the result.

\section{Service Sector Union}

The service sector union is relegated here to social movement status across the board. They were the only local to revel in the fact that they associated themselves with the Fairness Alliance, regarded to be one of the most progressive and most efficient human rights groups in the region. Since Fairness is the local champion of Gay, Lesbian, Bisexual, and Transsexual rights, they are quite controversial in that gay marriage is currently a hot-button issue. The local union's involvement with them can therefore be seen as quite progressive in the social welfare component.

The politics of the service sector local is the only area where it even comes close to the old tactics of business unionism. But because of the diligence of its worker education programs, and because it has no other choice than to make its political decisions by committee, the union retains its social movement status. If the officials at this local had their way, they would make these decisions by consensus, but the size of their membership and the non-political, sometimes uneducated nature of their rank and file prohibits it. They consider themselves lucky if they are able to persuade their workers to vote in the general elections; 
they have much lower expectations for their rank and file making more complex endorsement decisions and participating in lobbying efforts.

In organizing and servicing its members, this local is totally up to speed in the social movement realm. The mass servicing is an efficient tool not only for the benefit of the worker, but for the promotion of the union. The organizers are all at once able to see to members' needs in regards to accessible benefits, and help them with all manner of education and training opportunities.

This union's members are also subject to institutionalized discrimination, which unfortunately is still with us today. The jobs that their members fill are those that many people do not want; they work in meat-packing and processing plants, and retail stores, where forced concessions of the 1980s and 1990s have made these jobs even less desirable because of pay and benefit cuts. Since many of these positions no longer pay a good wage, women and people of color have been filling them more frequently in the last three decades. This can cause problems, especially in communicating with the immigrant population, but this local bends over backwards to try to resolve the language and cultural barriers. And the union's involvement in civil rights issues is second to none.

As a member of the CtW Federation, this union is poised to make great strides in the coming years in the rebuilding of the labor movement. They will be in the forefront of the push to organize retail workers, inevitably the first segment of the American workplace that will come under siege when the battle begins. 
And with their undeniable social movement union status, they will be well equipped to handle it.

\begin{tabular}{|l|l|l|l|}
\hline ISSUES & Craft Local & Public Sector & Service Sector \\
\hline Social Welfare & Business & Social Unionism & Social Unionism \\
\hline Pnionism & Business & Social Unionism & Social Unionism \\
\hline $\begin{array}{l}\text { Organizing } \\
\text { Unionism }\end{array}$ & Business & Business & \\
\hline $\begin{array}{l}\text { Race \& Gender } \\
\text { Attitude towards }\end{array}$ & Business & Unionism & Social Unionism \\
\hline Enionism & Unionism & Social Unionism & Social Unionism \\
\hline
\end{tabular}

Figure 4. Characteristics of local unions.

\section{Discussion}

The possibilities for union growth are endless, if the labor movement can take advantage of technology in order to reverse the negative image of unions in this country. Labor also needs to take care of the rank and file, by getting more of them involved and participating in the process. If at least one retail chain can be 
organized, then surely more will follow. This will then have an effect on the entire service sector, even the contingent workforce. If workers are desperate enough for better wages and benefits, and union organizers can reach enough people with the right impact, they can turn the tide of union sympathy. Like politics and many other things in our culture, union sympathy is cyclical; the Labor movement was in favor in the 1960s, and the 1980s with the short-lived Solidarity movement in Europe, and it will come back in fashion again very soon. There is little else, after all, that will insure that the majority of workers in America make a living wage, and that our middle class does not disappear altogether.

The public sector union will more than likely keep increasing its membership as long as member involvement remains as is or increases. Public sector unions have been experiencing steady increases in membership which are likely to continue. A possible boon for the public sector union in America is the eventual necessity of a nationalized, government run healthcare system. Although the prospect of unionization of that segment of the workforce could be seen as one of the obstacles to obtaining it, a single payer healthcare system seems inevitable in our future. If public sector unions are to have social movement status in the organizing arena, they will be forward-thinking enough to be poised and ready to organize the workers in this market. Perhaps because the public sector unions are the only ones studied who have enjoyed growth instead 
of decline in the last fifty years, they are less concerned with reaching out and increasing organizing resources.

The largest problem in the local public sector union is their incorporation with the city/county government merger. Although city and county officials have had their own problems with the new consolidated government, they are probably delighted that the union has had to expend so much time and energy focusing on the equitable merging of government employees and work units. This leaves less time to file grievances and properly represent their membership. The old problem of raiding has reared its head again for the public sector union; when other unions get lazy, the easy thing to do is try to steal another, more preoccupied unions' members. Unfortunately, a union signatory to the CtW Federation has been accused of that here locally, another old school tactic that without question damages the image of the $21^{\text {st }}$ century movement.

The local trade official interviewed here sees the Carpenters' union, now part of the Change to Win Federation, as disruptive to their efforts to court government and industry leaders. This seems to be a throwback to the status quo of business unionism; the tactics used by the Carpenters are definitely old school, but they do seem to have much more member involvement and interest in the daily workings of the union. Which begs the question of tactics: how do unions gain a foothold in the enlarged service sector and regain their status in 
the trades? Should both types of unions use the same tactics? Are striking and picketing outdated?

The service sector union is and has been using technology, maybe not to the best of its ability, but using it nonetheless, to change the hearts and minds of the public. They claim that, through the use of an informational website, their international union has decreased foot traffic in a certain large retail chain by a huge percentage in one year's time. And their mass-servicing may work better in today's world than union meetings held at the hall. Taking the union directly to the jobsite is more relevant and expedient, in a world where corporations strive to sell conveniences.

The Labor Movement must, if it is to win, overcome the past 30 years of union stereotypes, the negative images of corruption, and the hate mongering of its corporate enemies. It must also impress on the unorganized worker the value of union membership, by gaining their trust and thereby gaining new energy and more rank and file involvement. This can only be done with a deft grassroots campaign for workers' hearts and minds, and has the potential to bring exponential growth and momentum to the American Labor Movement. 


\section{REFERENCES}

American Federation of State, County, and Municipal Employees Website. http://www.afscme.org/

Barker, Kathleen and Kathleen Christensen, Eds. (1998) Contingent Work. Ithaca, NY: ILR Press.

Besser, Terry L. (1996) Team Toyota Albany, NY: SUNY Press.

Bonacich, Edna and Fernando Gapasin. (2002) "Organizing Workers in Global/Flexible Capitalism" in Nissen, Bruce, Ed. Unions in a Globalized Environment: Changing Borders, Organizational Boundaries, and Social Roles. New York: M.E. Sharpe.

Bronfenbrenner, Kate, Sheldon Friedman, Richard W. Hurd, Rudolph A. Oswald, \& Ronald L. Seeber. (1998) Organizing to Win. Ithaca, NY: ILR Press.

Chaison, Gary N. and Joseph B. Rose. (1990) "New Measures of Organizing Effectiveness." Industrial Relations. 29:457-69.

Change to Win Federation website. http://changetowin.org/

Coker, Jeffrey W. (2002) Confronting America. (1998) "Making Labor Law Work" in Barker, Kathleen and Kathleen Christensen, Eds. Contingent Work. Ithaca, NY: ILR Press.

Creswell, John W. (2003) Research Design: Qualitative, Quantitative, and Mixed Method Approaches. Thousand Oaks, CA: Sage Publications.

Ehrenreich, Barbara. (2001) Nickel and Dimed. New York: Henry Holt \& Co.

Eimer, Stuart. (2002) "Labor and the 2000 Election: Reinventing Union Politics" Research in Political Sociology. Vol 10 Pp. 213-222.

Erlich, Mark \& Jeff Grabelsky. (2000) "Standing at a Crossroads: The Building Trades in the $21^{\text {st }}$ Century" Labor History 46, 4 November 421-445. 
Fletcher Jr., Bill. (2000) "Race, Gender, and Class: The Challenges Facing Labor Educators" Labor Studies Journal 25, 1 Spring 104+.

and Richard Hurd. (2000) "Is Organizing Enough? Race, Gender, \& Union Culture" New Labor Forum No. 6 June 30, 59 +.

Frabotta, David. (2000) "Wage War Could Exclude Those It Intends to Help" Hotel and Motel Management 215, 19 November 6, 72+.

Freeman, Richard B. \& James L. Medoff. (1984) What Do Unions Do? New York: Basic Books.

Galenson, Walter. (1986) "The Historical Role of American Trade Unionism" in Unions in Transition Cambridge: Harvard University Press.

Green, Max. (1996) Epitaph for American Labor: How Union Leaders Lost Touch with America Washington: AEI Press.

Hassan, Khalil. (2000) "The Future of the Labor Left" Monthly Review JulyAugust Pp. 60-83.

Heckscher, Charles. (2001) "Living With Flexibility" in Lowell Turner, Harry C. Katz, \& Richard Hurd, Eds. Rekindling the Movement: Labor's Quest for Relevance in the Twenty-First Century. Ithaca: Cornell University Press.

Kutalik, Chris. (2005) "Behind the Split" September labornotes.org.

Lopez, Steven Henry. (2004) Reorganizing the Rust Belt: An Inside Study of the American Labor Movement. Berkeley: University of California Press.

Master, Bob, and Hetty Rosenstein. (2005) "Is Change to Win a New ClO?" September labornotes.org

McCall, Leslie. (2000) "Sources of Racial Wage Inequality in Metropolitan Labor Markets: Racial, Ethnic, and Gender Differences" American Sociological Review 66 August 520-541.

McCracken, Grant. (1988) The Long Interview. Newbury Park, CA: Sage Publications. 
Meyerson, Harold. (2001) "California's Progressive Mosaic" The American Prospect June 18 17-23.

Milkman, Ruth, Ed. (2000) Organizing Immigrants: The Challenge for Unions in Contemporary California. Ithaca: Cornell University Press.

Milkman, Ruth, and Kim Voss, eds. (2004) Rebuiding Labor: Organizing and Organizers in the New Union Movement. Ithaca: Cornell University Press.

Nissen, Bruce, Ed. (1999). Which Direction for Organized Labor? Detroit: Wayne State University Press.

(2002) Unions in a Globalized Environment: Changing Borders, Organizational Boundaries, and Social Roles. New York: M.E. Sharpe.

Reskin, Barbara F., and Irene Padavic. (1994) "Work \& Gender" in Women \& Men at Work. Thousand Oaks, California: Pine Forge Press.

Rubin, Herbert J. and Irene S. Rubin. (2005) Qualitative Interviewing: The Art of Hearing Data, Second Edition. Thousand Oaks, CA: Sage Publications.

Spalter-Roth, Roberta, and Heidi Hartmann. (1998) "Gauging the Consequences for Gender Relations, Pay Equity, and the Public Purse" in Barker, Kathleen and Kathleen Christensen, Eds. Contingent Work. Ithaca, New York: ILR Press.

Stover, Ronald G., Melodie L. Lichty and Penny W. Stover. (1999) Industrial Societies: An Evolutionary Perspective Upper Saddle River, New Jersey: Prentice-Hall.

Sweeney, John J. (1996) America Needs A Raise: Fighting for Economic Security and Social Justice. Boston: Houghton Mifflin.

Tait, Vanessa Maura. (2000) Poor Workers' Unions: Rebuilding the Labor Movement from Below. Unpublished Ph.D. Dissertation. University of California, Santa Cruz.

Tilly, Chris. (1996) Half a Job. Philadelphia: Temple University Press.

Troy, Leo. (2004) The Twilight of the Old Unionism. Armonk, New York: M.E.Sharpe. 
Turner, Lowell, and Richard W. Hurd. (2001) "Building Social Movement Unionism: The Transformation of the American Labor Movement" in Lowell Turner, Harry C. Katz, \& Richard Hurd, Eds. Rekindling the Movement: Labor's Quest for Relevance in the Twenty-First Century. Ithaca: Cornell University Press.

United States Department of Labor, Bureau of Labor Statistics News, 1990.

United States Department of Labor, Bureau of Labor Statistics website. http://www.bls.gov

Weinbaum, Eve S. (1999) "Organizing Labor in an Era of Contingent Work and Globalization" in Bruce Nissen, Ed. Which Direction for Organized Labor? Detroit: Wayne State University Press.

Weir, Stan (2004) Singlejack Solidarity. Minneapolis: University of Minnesota Press.

Wheeler, Hoyt N. (2002) The Future of the American Labor Movement. Cambridge: Cambridge University Press.

Wunnava, Phanindra P. \& Noga O. Peled. (1999) "Union Wage Premiums by Gender and Race: Evidence from PSID 1980-1992" Journal of Labor Research 20, 3 Summer 415+. 


\section{CURRICULUM VITAE}

NAME: $\quad$ Jo Ann Shumate

ADDRESS: $\quad 827$ Parkway Drive

Louisville, KY 40217

DOB: $\quad$ June 28, 1958

EDUCATION

\& TRAINING: $\quad$ Louisville Electrical Joint Apprenticeship \& Training Council Apprenticeship Completed

1987

University of Louisville

B.S., Sociology

2001

AWARDS: Apprentice of the Year

The 88 Club

1987

Dean's Scholar

2000

EMPLOYMENT: Coordinator for Ready to Work / Work \& Learn Programs Jefferson Community \& Technical College

2004 - Present

Graduate Teaching Assistant, Sociology

University of Louisville

$2002-03$

Journeyman Electrician

1987 - 98

Instructor for LEJATC

1991 - 94 